Swarthmore College

Works

$1-1-2011$

\title{
The Trauma Of Post-Empire: Review Of Serguei Oushakine's The Patriotism Of Despair
}

\author{
Maya Nadkarni \\ Swarthmore College, mnadkar1@swarthmore.edu
}

Follow this and additional works at: https://works.swarthmore.edu/fac-soc-anth

Part of the Anthropology Commons

\section{Recommended Citation}

Maya Nadkarni. (2011). "The Trauma Of Post-Empire: Review Of Serguei Oushakine's The Patriotism Of Despair". Ab Imperio. Volume 1, 262-268.

https://works.swarthmore.edu/fac-soc-anth/109

This work is brought to you for free by Swarthmore College Libraries' Works. It has been accepted for inclusion in Sociology \& Anthropology Faculty Works by an authorized administrator of Works. For more information, please contact myworks@swarthmore.edu. 


\section{THE TRAUMA OF POST-EMPIRE:}

\section{REVIEW OF SERGUEI OUSHAKINE'S}

\section{THE PATRIOTISM OF DESPAIR}

Serguei Oushakine begins his analysis of trauma and national reconstruction in Russia by describing how the uneven pace of post-Soviet development has threatened even the possibilities of movement through the cityscape of Barnaul, the provincial capital of the Altai region and the main field site for Oushakine's research between 2001 and 2003. The commercialization of once-private apartments, with the concomitant demand that these new enterprises maintain the sidewalks outside their entrances, has resulted in what Oushakine calls the "semi-privatization" of public space: sidewalks composed of a hazardous patchwork of brick, asphalt, and cinder blocks that literalizes the fragmentation of Russia's cultural landscape after the end of state socialism. ${ }^{1}$

Such vivid images of the fracturing of a once-coherent social space are familiar tropes in studies of postsocialism, as is Oushakine's concern for how postsocialist subjects have responded to such physical and symbolic disruption: the collapse of established narratives, social organization, regimes of value, and indeed the entire symbolic edifice that structured not only the official culture of state socialism but also the everyday life of its citizens. What

${ }^{1}$ Serguei Alex. Oushakine. The Patriotism of Despair: Nation, War, and Loss in Russia. Ithaca, 2009. Pp. 19-20. 
sets The Patriotism of Despair apart, however, is Oushakine's assertion that these experiences of loss have paradoxically become the very source of new forms of collectivity and new narratives of national belonging. In other words, it is precisely such claims to real or imagined trauma that have become the means through which Russians "remake post-Soviet life" (to play upon the title of Humphrey's earlier study of Russia's postsocialist transformation). ${ }^{2}$

To demonstrate this, Oushakine draws upon an impressively ambitious array of ethnographic material and theoretical approaches to examine a range of groups united by various forms of suffering. The first half of the book examines how nationalist scholars and political activists seek to make sense of an unpredictable social order perceived to be traumatized by the "tragic" decline of Russian ethnicity and the disruption of the country's transition to market capitalism. The second half turns from imagined to personal loss in order to investigate the ways in which both Chechen war veterans and the mothers of soldiers killed in that conflict struggle for state recognition of their sacrifice and bereavement.

Participation in such "communities of loss," Oushakine argues, empowers their subjects in two ways. First, the shared experience of trauma enables these groups to naturalize themselves around exclusionary kinship ties, whether the brotherhood of veterans or the racist construction of a national family through a biologically and geographically determined Russian "etnos." Communities of loss thus function as anchors of stability in the social chaos produced by the demise of Soviet collectivity and the collapse of state institutions. Second, and perhaps most important, the very solidarity these communities provide offers their members the opportunity not only for collective validation but also for renewed identification with the traumatized Russian nation itself. Such wounded attachment to nationhood is what Oushakine terms the "patriotism of despair": "an emotionally charged set of symbolic practices called upon to mediate relations among individuals, nation, and state and thus to provide communities of loss with socially meaningful subject positions."3

No summary can do justice to the richness of Oushakine's ethnographic analysis of the socialities produced by the common experience of loss. There are, however, several aspects of his understanding of the cultural trauma that organizes these communities that I would like to highlight as especially productive for future scholarship. To begin with, Oushakine's argument

${ }^{2}$ Caroline Humphrey. The Unmaking of Soviet Life: Everyday Economies after Socialism. Ithaca, 2002.

${ }^{3}$ Oushakine. The Patriotism of Despair. P. 5. 


\section{Maya Nadkarni, The Trauma of Post-Empire}

for analyzing trauma as symbolically generative and thus materialized in "relations, things, and discourses"4 provides an important alternative to the literature on cultural and personal trauma that has insisted upon the unrepresentability of trauma and the obstacles it poses to individual and collective attempts to create meaning. (Among others, Oushakine cites the works of Caruth, Bar-On, Friedlander, Homans, and Winter; I would add Felman and Laub's influential work on trauma and witnessing as well.) ${ }^{5}$ As such, Oushakine joins scholars of Russia and elsewhere who have similarly argued for the cultural productivities of crisis and loss. ${ }^{6}$

Oushakine raises the stakes of such analysis, however, in the very pessimism of his cultural diagnosis: post-Soviet Russian life, he argues, is characterized by both a narrowing of affective capacity (that is, the hopelessness of despair) and the evacuation of positive symbolic content (a position that I believe he first proposed in his 2000 article on post-Soviet aphasia). ${ }^{7}$ For Oushakine, what is at stake in the patriotism of despair is thus not an act of mourning that might "come to terms" or "work through" loss (to borrow common phrases from the literature on cultural memory), but rather the positivization of lack itself, ${ }^{8}$ through new possibilities of collectivity, kinship, and national belonging that emerge from-but crucially do not resolve or remediate - traumatic experience. In other words, despite the productivity it inspires, the traumatic wound itself can never heal. Instead, for Oushakine's subjects, the circular logic of traumatic repetition makes loss "their beginning, their driving force, their destination."

${ }^{4}$ Ibid. P. 6.

${ }^{5}$ Dan Bar-on. The Indescribable and the Undiscussable, Reconstructing Human Discourse After Trauma. Budapest, 1999; Cathy Caruth. Unclaimed Experience: Trauma, Narrative, and History. Baltimore, 1996; Shoshana Felman, Dori Laub (Eds.). Testimony: Crises of Witnessing in Literature, Psychoanalysis and History. New York, 1991; Saul Friedlander (Ed.). Probing the Limits of Representation: Nazism and the "Final Solution." Cambridge, 1992; Peter Homans (Ed.). The Ambiguity of Mourning and Memory at Century's End. Charlottesville, 2000; Jay Winter. Sites of Memory, Sites of Mourning: The Great War in European Cultural History. Cambridge, 1995.

${ }^{6}$ David Eng, David Kazanjian (Eds.). Loss. Berkeley, 2002; Claudio Lomnitz-Adler. Times of Crisis: Historicity, Sacrifice, and the Spectacle of Debacle in Mexico City // Public Culture. 2003. Vol. 15. Pp. 127-147; Olga Shevchenko. Crisis and the Everyday in Postsocialist Moscow. Indiana, 2009; Nancy Ries. Russian Talk: Culture and Conversation During Perestroika. Ithaca, 1997.

${ }^{7}$ Serguei Alex. Oushakine. In the State of Post-Soviet Aphasia: Symbolic Development in Contemporary Russia // Europe-Asia Studies. 2000. Vol. 52. Pp. 991-1016.

${ }^{8}$ Oushakine. The Patriotism of Despair. P. 207.

${ }^{9}$ Ibid. P. 4. 
Moreover, Oushakine demonstrates that just as the irresolution of trauma fuels its cultural productivity, the very incommunicability of trauma is what endows it with inconvertible value. That is, the experience of trauma cannot be circulated or exchanged; rather it is the untranslatability of its "shared substance" that hold communities of loss together and excludes those who have not suffered similarly. ${ }^{10}$ As such, the patriotism of despair illuminates the broader crisis in values produced by Russia's entrance into capitalism. After decades in which access to goods was determined not by money but by social relationships, post-Soviet claims to traumatic injury (such as the memory of war) are thus also claims to a value that cannot be monetized - and therefore subjected to the amoral and arbitrary logic of the market economy. Indeed it is the catastrophe of capitalism itself that impels the activists and scholars Oushakine studies in the first half of his book to re-narrate Russia and its painful heritage as a source of "inalienable wealth": "inconvertible values and an untranslatable history, framed in a vision of an exceptional Russian path."11 Yet, as the second half of his book makes clear, while such claims to take national value out of global circulation can have mobilizing force, the inconvertibility of trauma can also become another source of wounding, as when the state refuses to recognize the military sacrifice of Chechen war veterans, much less exchange this sacrifice for adequate compensation - whether to the veterans themselves or their bereaved parents.

This experience of bereavement - perhaps the most agonizing of the many traumas Oushakine examines in his book - leads me to list one more contribution that Oushakine makes to the study of trauma. In his final chapter on grieving mothers who lost their sons to the Chechen conflict, Oushakine examines the material production through which these mothers make the personal losses of a forgotten war visible in public space: grave monuments, memorial books, and new commemorative spaces. Oushakine draws here from Winnicott's notion of "transitional objects"12 to illuminate how this community of loss invests such sites of memory with the work of mourning itself; as he notes, managing these traces of dead sons becomes as important as managing the original loss. What is key to Oushakine's analysis, however, is that rather than facilitate detachment, as in Winnicott's model, these objects and the practices they inspire "map out no transitions." ${ }^{13}$ Rather,

${ }^{10}$ Ibid. P. 7.

${ }^{11}$ Ibid. Pp. 21, 13.

${ }^{12}$ D. W. Winnicott. Playing and Reality. New York, 1971.

${ }^{13}$ Oushakine. The Patriotism of Despair. P. 229. 


\section{Maya Nadkarni, The Trauma of Post-Empire}

they maintain the very centrality of loss in these mothers' everyday lives, structured by visits to the graves they carefully maintain and participation in communities of bereavement.

With such insights, Oushakine's ethnography of the cultural productivity of trauma and the "work of the negative"14 thus sets the standard for future work concerned with the dynamics of cultural memory, mourning, and loss, whether under postsocialism or in the aftermath of historical trauma more generally. For this reason, I am inspired to explore some of the implications of his choice to frame his analysis not in terms of trauma or memory itself, but the emotionally charged cultural logic of "despair." Throughout his analysis, Oushakine uses "despair" in its everyday sense as a synonym for pessimism and hopelessness, in order to highlight that while the experiences of loss and disillusionment he describes are powerful sources of new collective and national identifications, such wounded attachments cannot transcend but only reinscribe the fact of loss. In his introduction, however, Oushakine cites a potentially more generative definition of despair by the scholar and critic Nikolai Punin, who considered despair his "way of keeping a distance from the unbearable reality" rather than being consumed by circumstances outside his control. ${ }^{15}$ Oushakine distinguishes his use of despair from Punin's by noting that what is crucial about the cases he analyzes is that such pessimism does not motivate the resistance of private retreat, but rather inspires narratives of national belonging: that is, the experience of despair has the potential not only to alienate but also to enable new forms of social integration. Nonetheless, what Oushakine appears to share with Punin in this discussion is a notion of despair that contains both defeat and the will to keep fighting: as he notes, the Russian translation of the term (otchaianie) means not only "lost hope and dejection but also decisiveness and courage without any constraint." 16

While many of the stories Oushakine tells in the chapters that follow indeed bring such "courage without any constraint" to life, I would be eager to see him pursue further the implications of this more dialectical understanding of despair for his analysis. In particular, I wonder whether the capacity for courage and distancing might also make possible critical reflection - or even hope. Could such a formulation of despair provide a potential exit from the circularity of traumatic repetition? I am reminded here of Bloch's argument

\footnotetext{
${ }^{14}$ André Green. The Work of the Negative / Transl. Andrew Weller. London, 1999.

${ }^{15}$ Nikolai Punin. Mir svetel liubov’iu: dnevniki, pis'ma. Moscow, 2000. P. 375, quoted in Oushakine. The Patriotism of Despair. P. 5.

${ }^{16}$ Oushakine. The Patriotism of Despair. P. 6. 
that disappointability is the very condition of hope. ${ }^{17}$ Similarly, recent work on the disillusionment with democracy and the longing for normality in the former Yugoslavia has been concerned with understanding how laments of loss, frustration, and despair at the failed promises of the future have also made possible new forms of hope and expectation. ${ }^{18}$

My point in referencing this body of scholarship is not to suggest that Oushakine has somehow missed redemptive possibilities in his ethnographic material. Rather, I introduce this comparative perspective to ask if there are practices of post-Soviet life in Barnaul that succeed in the production of content that is positive in both senses of the term, and whose analysis might thus set the "patriotism of despair" in even sharper relief. Alternately, I would be curious to learn what is specific to the Russian (or Barnaul) experience that mandates against the very possibility of such hopefulness. It should be noted that Oushakine has provided a number of reasons for why he believes Russia to be equipped with a more limited "cultural repertoire" than other post-Soviet nations. Russia lacks both a viable vision of presocialist identity to which it might return and the possibility of future membership in NATO or the EU as a model to which it might aspire. Moreover, the very dominance of Russian identity under socialism made it the "blank spot" on the canvas of Soviet nationalities. What is thus at stake, Oushakine argues, is not merely a question of reconstructing national identity, but rather the post-Soviet impossibility of producing positive symbolic content. ${ }^{19}$

Yet I wonder if one needs an established vocabulary in "positive and/or non-imperial terms" 20 in order to imagine and voice the desire that things might simply be otherwise. Does the lack of a viable alternative invalidate the hopefulness of such yearning? Indeed, the urgency that animates Oushakine's subjects' attempts to make sense of Russia's national and economic transformations or to achieve recognition of their sacrifices and bereavement would seem to make visible a certain optimism in their very structure of expectation, even if - as Oushakine's book so poignantly demonstrates -

${ }^{17}$ Ernst Bloch. Can Hope Be Disappointed? // Literary Essays / Transl. A. Joron. Stanford, 1998. Pp. 339-345. In this formulation, as Richter notes, despair harbors hope as its "own most inner other." See Gerhard Richter. Can Hope Be Disappointed? Contextualizing a Blochian Question // Sympoke. 2006. Vol. 4. Pp. 42-54.

${ }^{18}$ A summary of the direction of this work can be found in Andrew Gilbert, Jessica Greenberg, Elissa Helms and Stef Jansen. Commentary: Reconsidering Postsocialism from the Margins of Europe: Hope, Time, and Normalcy in post-Yugoslav Societies // Anthropology News. 2008. November. Pp. 10-11.

${ }^{19}$ Oushakine. The Patriotism of Despair. Pp. 10-11.

${ }^{20}$ Ibid. P. 11. 
such efforts inevitably fail to overcome the fact of the loss that motivated them. That is, while the fragmented sidewalks of Barnaul may endanger their pedestrians, each patch nonetheless testifies to the longing of its caretakers to create a place of their own in the fractured post-Soviet landscape.

For both its ethnographic sensitivity and theoretical rigor, The Patriotism of Despair is a crucial contribution not only to the scholarship on Russia and postsocialism but also to studies of trauma, nationalism, and cultural transformation more generally. (Moreover, its chapters on war veterans and bereaved mothers are a student favorite in an undergraduate course I am currently teaching about comparative perspectives on memory and nation.) I look forward to wherever Oushakine's insights into the dynamics of loss and the productivities of pessimism take him next.

\section{SUMMARY}

Майя Надкарни видит основной клад Ушакина в антропологию постсоциализма в том, что он продемонстрировал, как новые коллективные идентичности строятся на травматическом опыте, порожденном постсоветской фрагментацией. Особенно продуктивным для понимания постсоветских реалий является тезис Ушакина о смыслопорождающем потенциале потери и травмы, и об отсутствии позитивного содержания как основы новых постсоветских солидарностей. Последнее является следствием фиксации на оплакивании потери и травме как источниках дискурсов себя и общества. Надкарни также обращает внимание на еще один аспект, связанный с описанной Ушакиным культурой оплакивания: объекты, которые должны способствовать преодолению утраты, такие как могилы и памятники, которые ставят солдатские матери, напротив, способствуют переориентации с самой потери на процесс поддержания этих объектов и центральность травмы. Далее Надкарни обращается к представленной в книге концепции отчаяния и цикличности в проживании травмы, и задается вопросом: могут ли “сообщества утраты" также генерировать надежду и способствовать возрождению социальных связей? Она подвергает сомнению тезис Ушакина о том, что в постсоветской России отсутствует позитивное содержание, которое могло бы питать национальное воображение. Надкарни считает, что сами описанные Ушакиным “сообщества потери” свидетельствуют об определенном творческом потенциале социального воображения. 268 